\title{
REKOMENDASI PEMBANGUNAN PERKEBUNAN KOPI MASYARAKAT SINDANG MELALUI KAJIAN ETHNOAGRICULTURE
}

\author{
Paisal Ansiska ${ }^{1 *}$, Ela Hasri Windari ${ }^{1}$, Indriati Meilina Sari ${ }^{2}$ \\ ${ }^{1}$ Program Studi Sains Perkopian Univerisitas Pat Petulai \\ ${ }^{2}$ Program Studi Holtikultura Akademi Komunitas Rejang Lebong
}

\begin{abstract}
ABSTRAK
Masyarakat yang masih kental dengan pengaruh kebiasaan Praktik tradisional dalam hal pertanian adalah Masyarakat Sindang. Masyarakat Sindang adalah masyarakat asli Kota Lubuklinggau yang sebagian besar menetap di pelosok kota Lubuklinggau. Tujuan dari penelitian ini adalah untuk mengungkap bagaimana praktik perkebunan kopi yang dilaukan masyarakat Sindang dan memberikan rekomendasi pembangunan perkebunan kopi masyarakat sindang. Metode yang dilakukan dalam penelitian ini menggunakan pendekatan emik dan etik dengan metode observasi wawancara terbuka dan terstruktur. Berdasarkan penelitian yang telah dilakukan dapat disimpulkan bahwa kegiatan ethnoagriculture perkebunan kopi pada masyarakat sindang dilakukan dengan tahapan Pembukaan Lahan, Penanaman, Pemeliharaan, Pengendalian Hama dan Penyakit, Pemanenan, Pasca Panen dan Pemasaran secara sederhada dan tradisional. Pembangunan perkebunan kopi masyarakat sindang dapat dilakukan dengan pengembangan sistem pertanian yang lebih konservatif, Melakukan penanaman tanaman pertanian yang lebih beragam guna untuk meningkatkan nilai fungsi lahan pertanian, Melakukan pengelolaan pasca panen untuk memberi nilai lebih, Mengadakan pelatihan/penyuluhan tentang manajemen keorganisasian dan pengelolaan perkebunan.

Kata Kunci: Tradisional, Sindang, Perkebunan Kopi.
\end{abstract}




\section{BAB I PENDAHULUAN}

Ethnoagriculture ialah bagian dari ilmu Etnobotani yang memfokuskan pemanfaatan dan pengelolaan sumberdaya hayati oleh masyarakat atau suatu suku tertentu untuk memenuhi kebutuhan hidupnya (Ansiska, 2017). Ethnoagriculture meninjau pengetahuan serta pemanfaatan botani dan ekologi oleh masyarakat. Pemanfaatan yang berpedoman dengan pengetahuan yang dimiliki secara turun temurun atau pengetahuan yang didapat dari pengalaman hubungan antara pelaku perkebunan kopi dengan lingkungan.

Pengetahuan tradisional ialah konsep atau sistem pengetahuan kebudayaan yang dimiliki oleh masyarakat adat secara turun temurun di suatu daerah dan berhubungan dengan praktik-praktik pemanfaatan serta pengelolaan sumberdaya alam secara lestari (Chapman 2007; Zent 2009; Pierotti 2011). Pengetahuan tersebut bersifat adaptif dan dinamis karena merupakan hasil pengalaman empiris dan pemahaman masyarakat adat terhadap kondisi di sekitarnya. Pada umumnya masyarakat yang masih memegang teguh pengetahuan tradisional warisan leluhurnya adalah masyarakat tradisional.

Salah satu Masyarakat yang masih kental dengan pengaruh kebiasaan Praktik tradisional dalam hal pertanian adalah Masyarakat Sindang Kelurahan Jukung Kecamatan Lubuklinggau Selatan I Kota Lubuklinggau. Masyarakat Sindang ialah masyarakat asli Kota Lubuklinggau yang sebagian besar menetap di pelosok kota Lubuklinggau. Pada umumnya Masyarakat Sindang masih memegang teguh pengetahuan atau kebiasaan tradisional tentang perkebunan kopi. Kebiasaan masyarakat Kelurahan Jukung tentang pengelolaan sumber daya perkebunan kopi telah menciptakan hubungan yang erat antara masyarakat dengan alam sekitar. Masyarakat Kelurahan Jukung telah lama memanfaatkan sumber daya perkebunan kopi sebagai sarana untuk memenuhi kebutuhan. Sektor perkebunan kopi merupakan salah satu sektor unggulan di Kota
Lubuklinggau, $48 \%$ dari luas daerah Kota Lubuklinggau digunakan sebagai lahan perkebunan kopi dan 99\% lahan perkebunan kopi didominasi oleh komoditi tanaman Karet, Kopi, tanaman buah-buahan (BPS, 2013).

Pertanian perkebunan kopi merupakan komoditas yang telah lama dilakukan oleh masyarakat Sindang. Kegiatan pertaniannya meliputi pengolahan lahan, penanaman, perawatan, pemanenan, pengolahan pasca panen yang dilakukan secara tradisional. Praktikpraktik pengetahuan tradisional tersebut dapat membuktikan bahwa pengetahuan tradisional masyarakat Sindang mengacu pada kearifan lokal budidaya. Seiring dengan kemajuan teknologi dan zaman pengetahuan tradisional mulai dilupakan dan beralih ke teknik budidaya konvensional, karena dipicu oleh tingginya laju degradasi alam dan faktor yang berasal dari luar komunitas Masyarakat. Menghilangnya pengetahuan tradisional akan berdampak negatif pada kelestarian lingkungan karena masyarakat tidak lagi mengetahui pola-pola pengelolaan dan pemanfaatan sumberdaya secara lestari (Caniago \& Siebert, 1998). Oleh karena itu, perlu dilakukan penelitian terhadap praktik-praktik Budidaya Tanaman Perkebunan kopi oleh masyarakat Sindang untuk melihat status pengetahuan tradisional dan kontribusinya dalam konservasi. Upaya yang dapat dilalukan adalah dengan melakukan evaluasi praktik-praktik Budidaya Tanaman Perkebunan kopi rakyat oleh masyarakat Sindang dengan menggunakan pendekatan ethnoagriculture.

Tujuan dari penelitian ini adalah untuk mengungkap bagaimana praktik perkebunan kopi yang dilaukan masyarakat Sindang dan memberikan rekomendasi pembangunan perkebunan kopi masyarakat sindang.

\section{BAB II METODE PENELITIAN}

\subsection{Tempat dan Waktu Penelitian}

Penelitian ini akan di Kelurahan Jukung, Kecamatan Lubuklinggau Selatan I, Kota Lubuklinggau, Provinsi Sumatera Selatan. Kelurahan ini memiliki status hukum definitif. 
Kelurahan Jukung memiliki topografi berupa daratan dengan ketinggian 129 meter di atas permukaan laut dengan luas daerah $3275 \mathrm{Ha}$.
Waktu penelitian ini dilakukan pada bulan januari 2019.

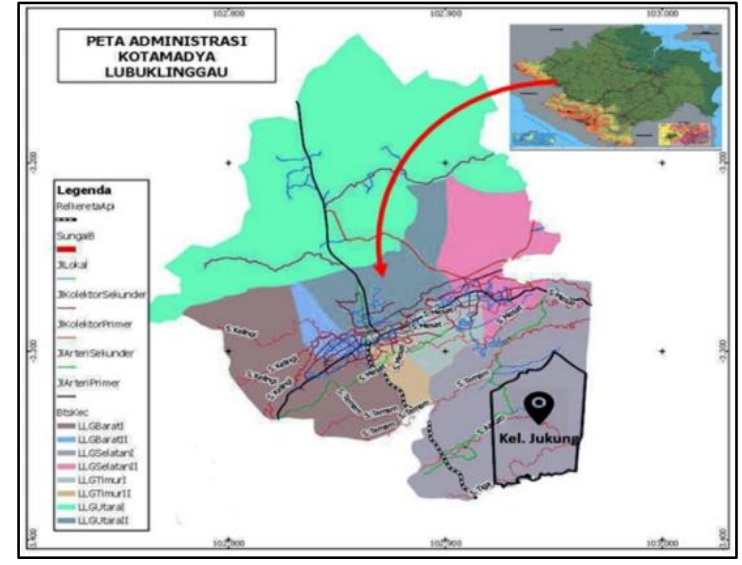

Gambar 1. Peta Administrasi Kota Lubuklinggau/Lokasi Penelitian

Kelurahan jukung

\subsection{Metode}

Kajian Ethnoagriculture perkebunan kopi masyarakat Sindang meliputi pengungkapan pengetahuan masyarakat Sindang mengenai pemanfaatan vegetasi di lingkungan perkebunan kopi. Untuk melakukan tahapan tersebut dilakukan menggunakan pendekatan emik dan etik dengan metode observasi wawancara terbuka dan terstruktur.

\subsection{Analisis Data}

Data keadaan ethnoagriculture yang telah didapat akan diolah menjadi perumusan strategi pembangunan dan konservasi pembangunan perkebunan kopi masyarakat Sindang terlebih dahulu dilakukan analisis potensi perkebunan kopi. Analisis yang dilakukan adalah dengan menggunakan analisis model SWOT (Strength, Weakness, Opportunity, dan Threat) untuk memaksimalkan kekuatan dan kesempatan serta mengurangi kelemahan dan mencegah ancaman yang ada di lingkungan perkebunan kopi masyarakat Sindang.

\section{BAB III HASIL DAN PEMBAHASAN}

\subsection{Pola Pikir Masyarakat Terhadap Lingkungan Perkebunan kopi \\ Bagi masyarakat Sindang sektor} perkebunan kopi tidaklah hanya sebagai usaha tani untuk menghasilkan produksi, melainkan sektor yang telah dipahami dan dijalani secara turun temurun dan telah menjadi jati diri masyarakat Sindang. Hidup sebagai petani perkebunan kopi bukan sekedar pilihan, tetapi juga merupakan realisasi dari keyakinan mereka. Menjadi petani merupakan rasa bersyukur atas ajaran yang telah diberikan generasi terdahulu, menjadi petani perkebunan kopi merupakan kegiatan untuk melestarikan alam, menjadi petani berarti mengolah tanah atau menghidupkan tanah. Tanah merupakan asal muasal manusia, dari tanahlah manusia berasal, dari tanah manusia mendapatkan kehidupan dan dari tanah pula manusia dapat meneruskan generasi. Hidup menjadi petani berarti selalu mengingat asal usul kehidupan manusia.

Pola fikir masyarakat tentang lingkungan perkebunan kopi telah merujuk pada kepercayaan animisme. Animisme ialah kepercayaan tentang adanya makhluk halus sebagai roh nenek moyang yang bersifat supernatural yang mempengaruhi suatu pola kehidupan (Tylor, 1974). Kepercayaan animisme masyarakat Sindang tercermin dari sikap masyarakatnya dalam pengelolaan hutan rakyat, yang dimana terdapat ritual pemberian sesaji atau aturan-aturan yang berkaitan dengan etika terhadap roh nenek moyangnya.

Keahlian masyarakat dan ketergantungannya pada sektor perkebunan kopi lebih besar dibandingkan pengelolaan sektor lain, hal ini terlihat dari jumlah petani yang melakukan budidaya tanaman perkebunan kopi lebih banyak dibandingkan komoditi 
hortikultura. Pada lingkungan perkebunan kopi tidak hanya terdapat tanaman yang dibudidayakan, tetapi juga terdapat tumbuhan liar (hortikultura) yang menjadi penunjang kehidupan masyarakat Sindang. Pemanfaatan tumbuhan di lingkungan pertanian menambah pandangan positif dan arti nilai lebih masyarakat Sindang di lingkungan perkebunan kopi. Karena tumbuhan yang berada pada tanaman perkebunan kopi dipergunakan setiap hari sebagai bahan makanan, obat-obatan, dan sebagai bahan ritual.

Masyarakat Sindang mempunyai ketergantungan yang tinggi terhadap sumberdaya hayati pada lingkungan perkebunan kopi. Pengetahuan mereka tentang teknik budidaya dan keanekaragaman tumbuhan sudah cukup baik jika dilihat dari jenis-jenis tumbuhan yang digunakan dalam kehidupan sehari-hari. Keanekaragaman kehidupan hidup mereka banyak bergantung pada sektor perkebunan kopi.

\subsection{Ethnoagriculture Perkebunan Kopi}

Selain melakukan agriculture perkebunan kopikaret, masyarakat Sindang juga melakukan agriculture perkebunan kopikopi. Tanaman kopi termasuk dalam famili Rubiaceae dan terdiri dari banyak jenis, yaitu Coffea arabica, Coffea robusta, dan coffea liberica. Pada budidaya tanaman kopi yang dilakukan masyarakat Sindang, jenis kopi yang dibudidayakan adalah coffea robusta. Tanaman kopi robusta dapat tumbuh di dataran rendah sampai dengan ketinggian 1000 meter di atas permukaan laut dan daerah dengan suhu lebih dari $20^{\circ} \mathrm{C}$. Pertumbuhan dan produksi kopi sangat tergantung pada keadaan iklim dan tanah. Jika dilihat dari syarat tumbuh tanaman dengan kondisi lingkungan masyarakat Sindang, keadaan lingkungan masyarakat Sindang tidak memenuhi syarat tumbuh. Keadaan yang lebih rendah yang mengakibatkan tingginya keadaan suhu. Jenis kopi robusta menghendaki tumbuh pada daerah dengan suhu sekitar 210-240C. Faktor suhu berpengaruh penting terhadap masa pertumbuhan vegetatif, makin tinggi elevasi akan semakin memperlambat pertumbuhan dan perkembangan tanaman kopi yang akhirnya akan mempengaruhi umur tanaman kopi saat produktif.
Agriculture perkebunan kopikopi yang dilakukan masyarakat Sindang dilakukan dengan cara sederhana dan tradisional, dimana teknologi yang diterapkan masih sangat sederhana, seperti penggunaan bibit, penggunaan pupuk, pemanenan, dan perlakukan pasca panen. Proses dan teknologi budidaya tanaman kopi pada masyarakat Sindang dapat dilihat pada penjelasan berikut:

1) Pembukaan Lahan

Pada pembukaan pada lahan perkebunan kopikopi masyarakat Sindang umumnya melakukan hal yang sama seperti yang dilakukan pada pembukaan perkebunan kopikaret dimana terdapat penebasan, dan penebangan.

a. Penebasan dan Penebangan

Pembukaan lahan biasanya dilakukan dengan cara penebasan dan penebangan. Dimana lahan yang akan dibuka sebagai perkebunan kopikopi biasanya lahan kopi yang sudah tidak produktif ataupun tanah warisan terdahulu yang belum tergarap. Penebasan dilakukan untuk membersihkan pohon atau semak belukar. Penebangan dilakukan untuk membersihkan pohon-pohon yang berdiameter besar. Pada jika lahan yang akan dibuka merupakan komoditi yang sama, umumnya pembukaan yang digunakan hanya menggunakan metode penebasan dengan menggunakan parang tebas atau dalam bahasa Sidangnya adalah mandau.

\section{b. Bahan Tanam}

Teknik yang digunakan dalam upaya perbanyakan tanaman kopi adalah teknik vegetatif menggunakan bagian dari tanaman dan generatif yang menggunakan benih atau biji. Perbanyakan menggunakan benih atau biji ini dilakukan menggunakan penyemaian dan pemindahan anakan bawah batang yang batang bibitnya berdiameter $\pm 5 \mathrm{~mm}$. Penyemaian benih dilakukan dengan cara yang sederhana seperti, memilih biji kopi yang sehat dan besar untuk dijadikan benih, menanamnya pada media tanam (polybag), melakukan perawatan benih, setelah benih memiliki lebih dari tiga pasang daun (lebih dari tiga bulan), benih siap untuk dipindahkan ke lahan perkebunan rakyat.

2) Penanaman 
Pada tahapan penanaman tanaman kopi masyarakat Sindang hanya mengira jarak tanam. Tetapi pada observasi yang telah dilakukan, umumnya jarak tanam yang dilakukan berkisar $170 \mathrm{~cm}$. Penanaman dilakukan dengan memberi lubang pada tanah sesuai kebutuhan bibit yang digunakan pada lahan yang telah dibersihkan (siap tanam). Untuk proses penanaman, tidak ada penambahan pupuk organik ataupun proses pengapuran ke dalam tanah sebelum penanaman.

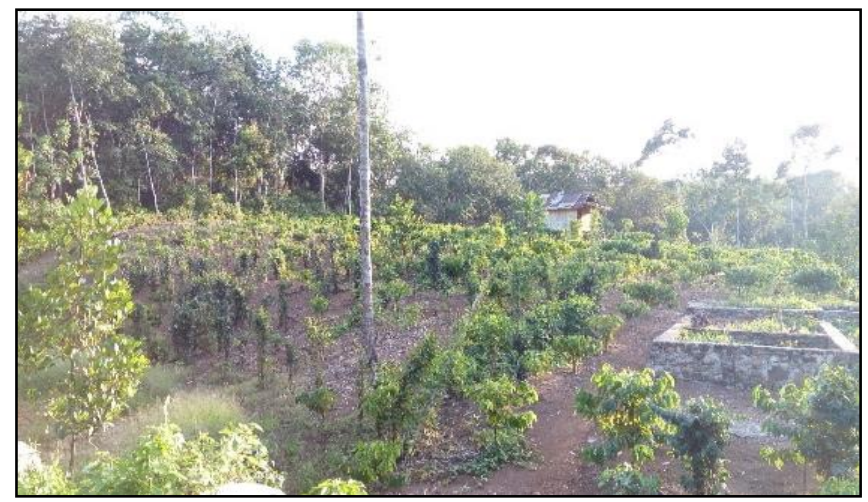

Gambar 2. Lahan Perkebunan Kopi

3) Pemeliharaan

Proses pemeliharaan yang dilakukan pada agriculture perkebunan kopikopi masyarakat Sindang melakukan dengan peralatan sederhana, pemeliharaan ini meliputi: (1) Penyulaman (2); Penyiangan (3); Penyiangan; (4) Pemangkasan, teknik pemangkasan yang dilakukan adalah teknik pangkas lepas panen (PLP) pada bagian tanaman kopi dengan cara memangkas bagian tanaman kopi yang telah dipanen lebih dari 3-6 kali panen, cabang kering, cabang cacing/ceker ayam.

4) Pengendalian Hama dan Penyakit

Kearifan lokal merupakan kecerdasan manusia yang dimiliki oleh kelompok etnis tertentu yang diperoleh melalui pengalaman masyarakat (Rahyono, 2009). Dalam masyarakat Sindang terdapat kearifan lokal penanggulangan hama dan penyakit yang merupakan ajaran dari leluhur. Penanggulangan hama menggunakan kepada bahan-bahan yang ada di lingkungannya. Hama yang terdapat pada lingkungan perkebunan kopimisalnya hama babi, monyet, ulat, dan sebagainya. Dibawah ini kearifan lokal masyarakat Sindang untuk penanggulangan hama dam penyakit di perkebunan rakyatnya adalah:

a. Penanggulangan Hama Babi

Babi merupakan hama terbesar pada setiap perkebunan, dalam masyarakat Sindang terdapat tiga teknologi penanggulangan hama babi, diantaranya:

\section{- Pagar bakar}

Pagar bakar merupakan teknologi pengusir hama babi yang sudah jarang digunakan. Teknologi ini mengacu pada prinsip musuh alami babi yang bertujuan untuk mengusir hama babi yang hendak masuk ke dalam lingkungan perkebunan rakyatnya. teknologi ini menggunakan bahan limbah rambut manusia dan kartu domino yang di renteng pada bilah bambu ditancapkan pada tepi lahan perkebunan rakyatnya kemudian dibakar. Pengaplikasian teknologi ini umunya dipasang mengelilingi tepi area kebun mereka dengan jarak 4 meter. Filosofi dari penggunaan rambut adalah sebagai pengecoh babi agar babi beranggapan ada macan yang merupakan musuh alami hama babi, sedangkan filosofi dari kartu domino adalah permainan domino adalah permainan yang berasal dari cina, sedangkan orang cina biasanya memakan babi. Pembakaran dilakukan agar bau yang disebarkan oleh limbah rambut dan kartu 
domino dapat mengecoh babi dari indra penciuman babi tersebut

- Tanju/Habewa (Pagar Bambu)

Penggunaan teknologi ini merupakan teknologi yang sering dipakai dalam masyarakat Sindang, teknologi ini adalah membuat pagar dari bilah bambu yang dibuat mengelilingi perkebunan rakyat. Bilahan bambu ditancapkan ke dalam tanah dengan pola setengah parabola dengan ketinggian 40-50 $\mathrm{cm}$. Bilahan bambu yang telah dijadikan pagar yang bertujuan untuk menangkal hama babi yang ingin masuk di perkebunan rakyat, dimana jika babi itu ingin masuk babi kebun hidung dari babi tersebut akan menabrak bilahan bambu tersebut sehingga hidung dari babi tersebut terluka dan babi tidak jadi masuk.

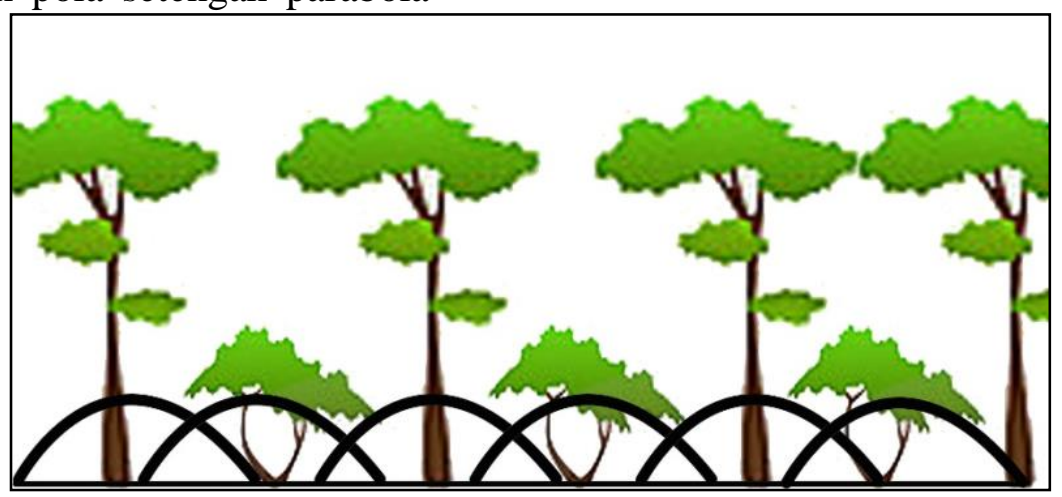

- Minyak Babi

Gambar 3. Penanggulangan Hama Babi Menggunakan Tanju/Habewa
Untuk mengusir hama babi yang sudah masuk area perkebunan rakyat. Masyarakat Sindang menggunakan minyak babi yang didapat dari hasil perburuan. Pengaplikasian minyak adalah dengan cara mengoleskan minyak babi di bagian batang. Cara kerja teknologi ini adalah menipu bahwa sudah ada babi di dalam lahan perkebunan kopitersebut, sehingga babi lain yang ingin masuk lahan perkebunan kopitidak jadi masuk ke lahan perkebunan kopikarena mereka beranggapan bahwa sudah lahan tersebut sudah dikuasai babi lain.

\section{b. Hama Monyet}

Dalam masyarakat Sindang hama monyet merupakan hama yang menyebabkan penurunan produksi buah. Untuk mengatasi ancaman dari datangnya hama monyet masyarakat Sindang umumnya mengikat anjing peliharaan mereka di bawah pondok/gubuk untuk menakut-nakuti hama monyet.

\section{c. Hama Serangga \\ Dalam masyarakat Sindang hama serangga juga merupakan hama yang menyebabkan penurunan produksi tanaman dan menyebabkan berbagai penyakit pada tanaman.}

Penanganan hama serangga dilakukan dengan membakar ranting-ranting bekas agar menimbulkan asap untuk mengusir hama yang masuk di lingkungan perkebunan masyarakat Sindang. Prinsip penggunaan ini seperti prinsip pengusiran nyamuk, dengan target hama serangga seperti wereng dan semut.

\section{5) Pemanenan}

Pada proses pemanenan tanaman kopi, hanya buah kopi yang ukurannya besar yang warnanya sudah merah merona. Proses pemanenan dilakukan dengan teknik manual, yaitu memetik langsung buah kopi yang sudah siap untuk dipanen.

\section{6) Pasca Panen dan Pemasaran}

Setelah melakukan pemanenan tanaman kopi, masyarakat terlebih dahulu menjemur kopi di bawah terik matahari. Dengan tujuan untuk menyusutkan kadar air di dalam buah kopi dan memisahkan antara kulit dan daging buah dengan biji kopi melepaskan yang akan dijual. Penjemuran juga dilakukan karena permintaan pasar yang menghendaki biji kopi dalam keadaan kering. Setelah mengalami pemisahan biji kopi. Pemasaran dilakukan dengan cara menjual langsung biji kopi kepada pengepul. 


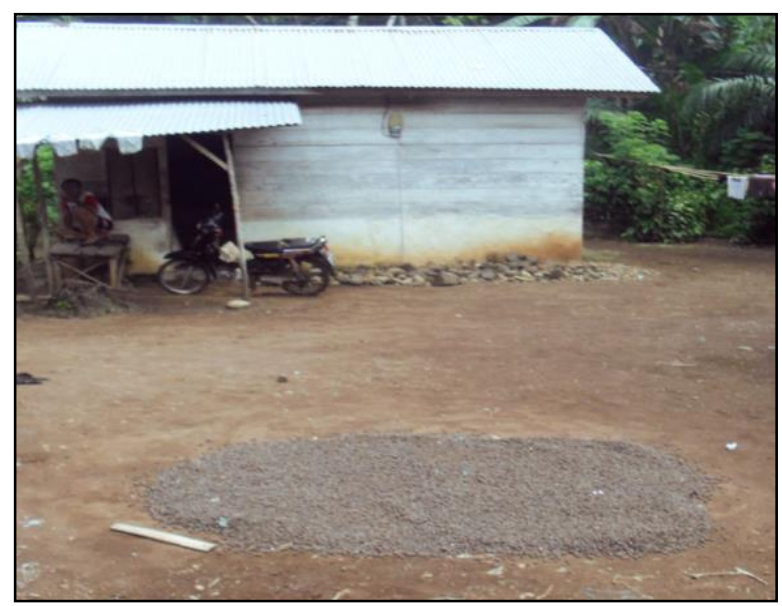

Gambar 4. Pasca Panen Kopi/Penjemuran Buah Kopi

\subsection{Perkebunan kopi Campuran}

Pada perkebunan kopi masyarakat Sindang komoditi yang di utamakan adalah karet, akan tetapi pada masyarakat Sindang ada komoditi lain seperti kopi, durian, kunyit, dan tanaman buah lainnya untuk menunjang kebutuhan hidup mereka. Pada tanaman yang termasuk sektor perkebunan kopi(bukan karet) biasanya ditanam setelah karet berumur lebih dari dua tahun sedangkan sebagian tumbuhan ada yang merupakan tumbuhan asli seperti durian. Sebelum tanaman karet ditanaman. tumbuhan asli tersebut umumnya dibiarkan tumbuh dan hasil produksinya dimanfaatkan.

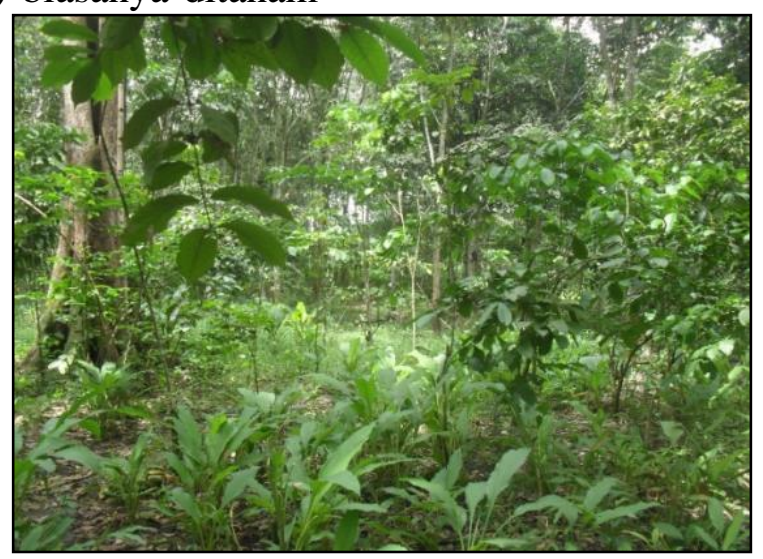

Gambar 5. Lahan Perkebunan Kopi Campuran

Pada sistem tanam campuran yang ditetapkan, tanaman umumnya tidak begitu diperhatikan pertumbuhannya. Pada studi area yang telah dilakukan, umumnya tanaman ditanam secara acak dengan prinsip dimana ada bidang yang kosong itulah bidang yang Untuk menunjang kegiatan tersebut lingkungan terdapat fasilitas pada lahan perkebunan kopimereka, fasilitas itu berupa pondok/gubuk yang dibangun menyerupai rumah panggung kecil. Pondok/gubuk dibangun menggunakan kayu yang tidak terpakai di sekitar dimanfaatkan. Umumnya penanaman dilakukan hanya dengan menyebarkan atau ditanam secara acak komoditi bermacam-macam pada lahan perkebunan kopi.

\subsection{Fasilitas didalam Perkebunan Kopi}

lahan perkebunan rakyat. Gubuk ini digunakan untuk beristirahat, bermalam, menyimpan hasil panen, dan peralatan perkebunan kopi. Di sekitar pondok terdapatpengapian yang berfungsi sebagai memasak dan penghangat dimalam hari. 

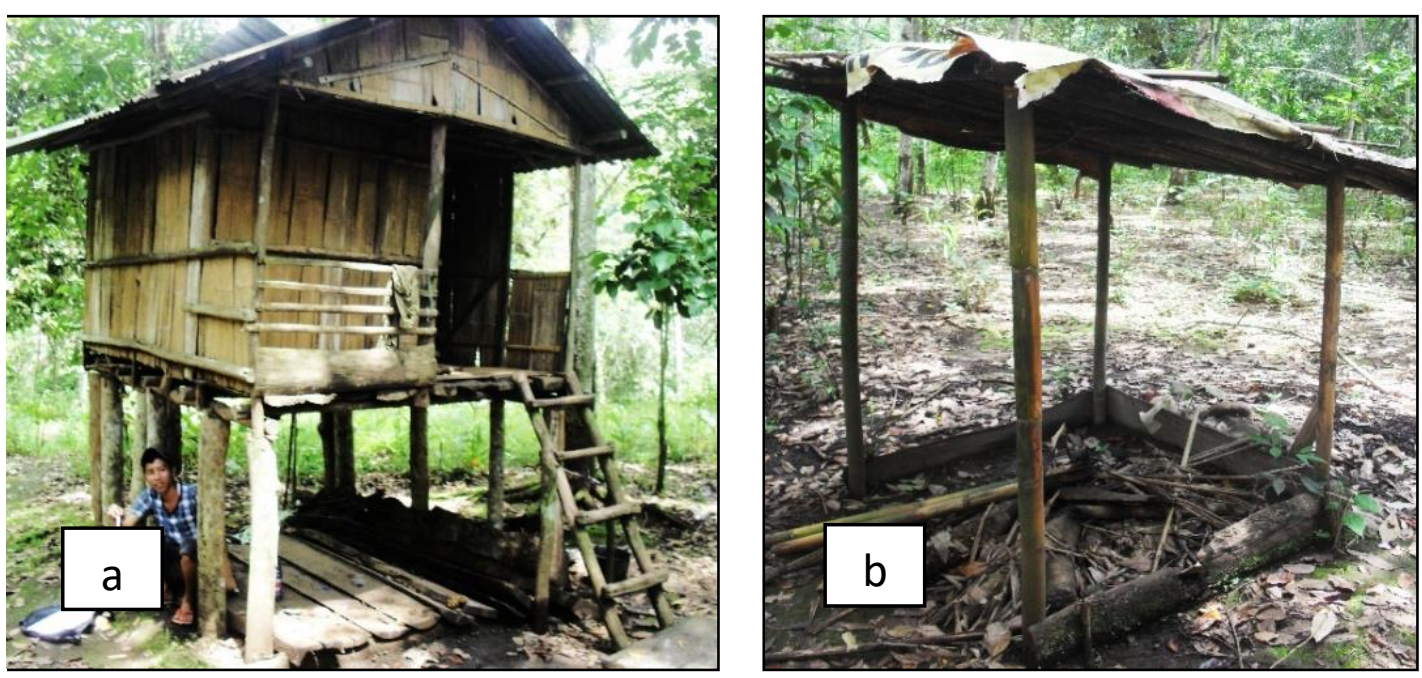

Gambar 6. Pondok/Gubuk (a) dan Pengapian (b) di Lahan Kebun Campuran

5.8 Rekomendasi Pembangunan Perkebunan Rakyat

Rekomendasi pembangunan perkebunan kopi dimasyarakat Sindang secara langsung dapat meningkatkan kualitas kuantitas hasil perkebunan rakyat. Dimana rekomendasi ini mengacu pada kondisi perkebunan kopi masyarakat Sindang. kondisi perkebunan kopi masyarakat Sindang yang terdiri dari faktor internal (kekuatan \& kelemahan) dan faktor eksternal (peluang \& ancaman). Melalui observasi langsung pada lingkungan perkebunan didapat analisis faktor-faktor kondisi lingkungan perkebunan kopi(internal dan eksternal) yang dapat dilihat Tabel 5.18. selanjutnya dilakukan penilaian terhadap faktor tersebut dengan pemberian skor yang dilakukan oleh responden yang diyakini mempunyai pengaruh kuat dalam pembangunan perkebunan kopi masyarakat Sindang.

Tabel 1. Analisis Faktor Internal (IFAS)

\begin{tabular}{|l|l|c|c|c|}
\hline \multicolumn{5}{|c|}{ Kelebihan } \\
\hline No & Pernyataan & Bobot & Pringkat & skor \\
\hline 1 & Kepemilikan lahan perkebunan yang masih luas & 0.06 & 3 & 0.18 \\
\hline 2 & Pengalaman berkebun petani & 0.09 & 3 & 0.26 \\
\hline 3 & Tanaman lokal lebih banyak dari pada tanaman eksotik & 0.09 & 3 & 0.27 \\
\hline 4 & $\begin{array}{l}\text { Banyak kearifan lokal atau tradisi yang masih } \\
\text { dipertahankan }\end{array}$ & 0.08 & 2 & 0.16 \\
\hline 5 & $\begin{array}{l}\text { Keadaan iklim dan lahan mendukung berbagai macam } \\
\text { pertumbuhan tanaman }\end{array}$ & 0.08 & 2 & 0.16 \\
\hline \multicolumn{1}{|c|}{ Kekurangan } & Bobot & Pringkat & skor \\
\hline No & Pernyataan & 0.13 & 5 & 0.65 \\
\hline 1 & Kelembagaan kelompok tani yang masih lemah & \multicolumn{2}{|c|}{} & 0.90 \\
\hline 2 & $\begin{array}{l}\text { Rendahnya kualitas dan kuantitas produksi tanaman } \\
\text { perkebunan }\end{array}$ & 0.18 & 5 & 0.40 \\
\hline 3 & $\begin{array}{l}\text { Inisiatif pengelolaan pasca panen masih tergolong } \\
\text { rendah }\end{array}$ & 0.10 & 4 & 0.56 \\
\hline 4 & Proses budidaya kurang intensif & 0.14 & 4 & \\
\hline
\end{tabular}


Tabel 2. Analisis Faktor Eksternal (EFAS)

\begin{tabular}{|c|c|c|c|c|}
\hline \multicolumn{5}{|c|}{ Peluang } \\
\hline No & Pernyataan & Bobot & Pringkat & skor \\
\hline 1 & Peran pemerintah dalam membantu petani perkebunan & 0.14 & 3.00 & 0.42 \\
\hline 2 & Dukungan infrastruk & 0.05 & 2.00 & 0.10 \\
\hline 3 & $\begin{array}{l}\text { Tumpang sari tanaman yang nilai ekonominya lebih } \\
\text { tinggi }\end{array}$ & 0.11 & 3.00 & 0.33 \\
\hline 4 & Pengembangan kawasan agrowisata berbasis perkebunan & 0.08 & 1.00 & 0.08 \\
\hline \multicolumn{5}{|c|}{ Ancaman } \\
\hline No & Pernyataan & Bobot & Pringkat & skor \\
\hline 1 & Ekpansi (pergantian fungsi) lahan & 0.05 & 1.00 & 0.05 \\
\hline 2 & Kualitas hasil panen milik pesaing & 0.11 & 3.00 & 0.33 \\
\hline 3 & Harga hasil panen yang pasang-surut & 0.10 & 3.00 & 0.30 \\
\hline 4 & $\begin{array}{l}\text { Tingginya harga bahan dan alat penunjang kegiatan } \\
\text { perkebunan kopi }\end{array}$ & 0.13 & 3.00 & 0.39 \\
\hline 5 & $\begin{array}{l}\text { Kerja sama petani dengan sumber inovasi yang masih } \\
\text { rendah }\end{array}$ & 0.16 & 4.00 & 0.64 \\
\hline
\end{tabular}

Dari data analisis faktor internal dan eksternal, data kemudian diolah menjadi data hasil analisis faktor internal dan eksternal.
Berpedoman dari hasil analisis faktor inilah rekomendasi pengelolaan perkebunan kopi dibuat.

Tabel 3. Hasil Analisis Faktor Internal dan Eksternal

\begin{tabular}{|c|c|c|c|}
\hline $\begin{array}{c}\text { Internal Factor Attrative } \\
\text { Score/IFAS }\end{array}$ & 3,63 & $\begin{array}{c}\text { Eksternal Factor } \\
\text { Attrative Score/EFAS }\end{array}$ & 2,84 \\
\hline Total Skor Kekuatan $(\mathrm{S})$ & 1,03 & Total Skor Peluang (O) & 0,93 \\
\hline Total skor kelemahan $(\mathrm{W})$ & 2,51 & Total Skor Ancaman $(\mathrm{T})$ & 1,71 \\
\hline S-W & $-1,78$ & O-T & $-0,78$ \\
\hline
\end{tabular}

Berdasarka tabel hasil analisis faktor internal dan eksternal diketahui titik koordinasi pengembangan perkebunan kopiSindang berada pada sumbu (X) -1,48 dan sumbu (Y) 0,78.
Koordinat tersebut berada pada kuadran 4 yang bearti dimana posisinya terdapat kelemahan internal dan ancaman eksternal pada kawasan perkebunan rakyat.

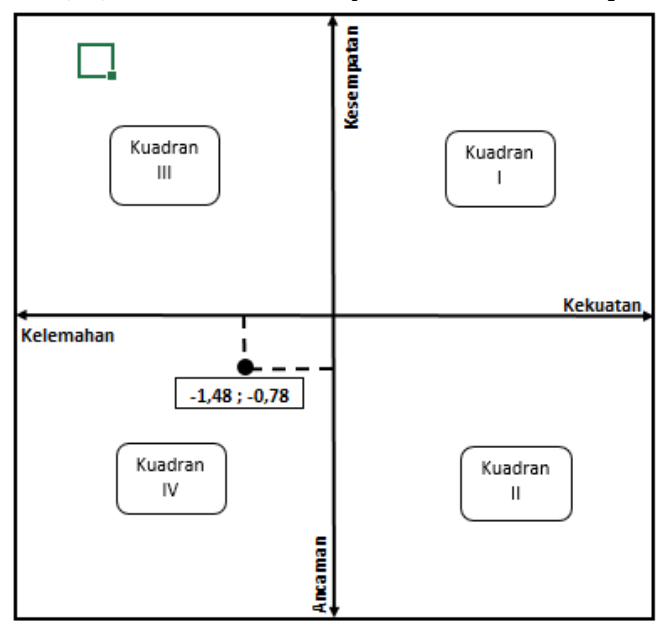


Gambar 7. Kuadran Analisis SWOT Pengembangan Perkebunan Rakyat

Berdasarkan Gambar 5.15, diketahui bahwa titik koordinat pembangunan pengelolaan perkebunan kopi berada pada variabel sumbu $\mathrm{X}$ $(-1,47)$ dan sumbu Y $(-0,89)$. Koordinat pada sumbu $\mathrm{X}$ dan $\mathrm{Y}$ tersebut berada pada kuadran IV. Berdasarkan kuadran tersebut, arahan pembangunan harus menekankan pada strategi untuk mengatasi kelemahan (internal) dan ancaman (eksternal). Berikut adalah alternatif strategi yang dapat dilakukan:

1) Pembangunan perkebunan kopidengan sistem pertanian yang lebih konservatif. (W1, W4, O4).

2) Melakukan penanaman tanaman pertanian yang lebih beragam guna untuk meningkatkan nilai fungsi lahan pertanian (W4, O1, O2).

3) Melakukan pengelolaan pasca panen untuk memberi nilai lebih (W3, W4, O3).

4) Mengadakan pelatihan/penyuluhan tentang manajemen keorganisasian dan pengelolaan perkebunan kopi (W2, O5).

\section{BAB IV \\ KESIMPULAN DAN SARAN}

\subsection{Kesimpulan}

Berdasarkan penelitian yang telah dilakukan dapat disimpulkan bahwa kegiatan ethnoagriculture perkebunan kopi pada masyarakat sindang dilakukan dengan tahapan Pembukaan Lahan, Penanaman, Pemeliharaan, Pengendalian Hama dan Penyakit, Pemanenan, Pasca Panen dan Pemasaran secara sederhada dan tradisional.

Pembangunan perkebunan kopi masyarakat sindang dapat dilakukan dengan pengembangan sistem pertanian yang lebih konservatif, Melakukan penanaman tanaman pertanian yang lebih beragam (polikultur) guna untuk meningkatkan nilai fungsi lahan pertanian, Melakukan pengelolaan pasca panen untuk memberi nilai lebih, Mengadakan pelatihan/penyuluhan tentang manajemen keorganisasian dan pengelolaan perkebunan.

\subsection{Saran}

Perlu adanya upaya lebih lanjut sebagai langkah pengenalan teknologi sederhana dan tepat guna untuk pengelolaan dan pemanfaatan sumberdaya lokal.

\section{DAFTAR PUSTAKA}

Ansiska P, Batoro J, Soelistyono R. 2017. Kajian Ethnoagriculture Perkebunan Rakyat Masyarakat Sindang Lubuklinggau, Sumatera Selatan. Tesis Universitas Brawijaya. Malang.

BPS, 2013. "Luas Tanaman Tahunan (m2) yang Diusahakan/Dikelola Rumah Tangga Usaha Perkebunan Menurut Wilayah dan Jenis Tanaman". Melalui: www.st2013.bps.go.id/dev2/index.php/site /tabel?tid=45\&wid=1600000000. [04/02/2016].

Chapman, PM., 2007. Traditional Ecological Knowledge (TEK) and ScientificWeight of Evidence Determinations. Marine Pollution Bulletin 54: 18391840.

Pierotti R., 2011. Indigenous Knowledge, Ecology, and Evolutionary Biology. New York: Routledge.

Rahyono FX., 2009. Kearifan Budaya dalam Kata. Jakarta: Wedatama Widya Sastra.

Tylor EB., 1974. "Primitive Culture: Researches into The Development of Mythology, Philosophy, Religion, Art, and Custom". New York: Gord Press. First published in 1871.

Zent S., 2009. Methodology for Developing a Vitality Index of Traditional Environmental Knowledge (VITEK) for the Project "Global Indicators of the Status and Trends of Linguistic Diversity and Tradit ional Knowledge." Principal Investigator Centro de Antropologia Instituto Venezolano de Investigaciones Cientificas (IVIC). Venezuela. 